Y. Chynchenko, V. Kharchenko. Integrated Algorithm for Compiling and Assessment of Direct Routes Restrictions in Free Route Airspace of Ukraine

UDC 656.7.052(045)

DOI $10.18372 / 2306-1472.88 .15987$

Yuriy Chynchenko ${ }^{1}$

Volodymyr Kharchenko ${ }^{2}$

\title{
INTEGRATED ALGORITHM FOR COMPILINGAND ASSESSMENT OF DIRECT ROUTES RESTRICTIONS IN FREE ROUTE AIRSPACE OF UKRAINE
}

\author{
12 National Aviation University, 1, Liubomyra Huzara ave.Kyiv, Ukraine 03058 \\ E-mails: ${ }^{1}$ chynchenko@gmail.com, ${ }^{2}$ kharch@nau.edu.ua
}

\begin{abstract}
The article describes the principles of acceptability assignment for direct routes restrictions in free route airspace of Ukraine for publication in Route Availability Document and further use by the Integrated Initial Flight Plan Processing System of Eurocontrol. The algorithms of correct generation of direct routes restrictions for the selected issues in a horizontal and vertical plane were proposed. As a main decision criteriafor these algorithms were chosen the shortest distance to the state boundary (in a horizontal plane) and space attitude (location) of aircraft (in avertical plane).

Keywords: direct routes restrictions, free route airspace concept, Route Availability Document, air traffic flows and capacity management, Integrated Initial Flight Plan Processing System, Free Route Airspace of Ukraine.
\end{abstract}

\section{Introduction}

Free Route Airspace (FRA)is an integral part of the regional European Air Traffic Management (ATM) network, which interfaces vertically or horizontally with adjoining fixed Air Traffic Services (ATS) route airspace [1].The harmonised application of the Flexible Use Airspace (FUA) Concept and Civil/Military Coordination [2] are necessary to ensure equal access to FRA and unified procedures and service provision for the benefit of all airspace users.

The setting of FRA vertical dimensions, especially the lower limit, shall not adversely impact adjacent areas, where FRA is not yet implemented or where only limited application of FRA is in place. These general recommendations shall be considered [1]:

- interconnectivity with adjoining airspace (preferably on a Pan-European network level);

- the minimum level should be the lowest feasible, but considering the traffic complexity, regular aircraft types, airspace use and features of national procedures.

To maximise the efficiency of FRA utilisation while maintaining target level of safety (adopted on a national level) [3], all efforts need to be made to realign the fixed ATS route network in adjacent airspace not applying FRA. In a midterm perspectivethe fixed ATS route network will remain in operation below the FRA, this underlying ATS route network shall be refined and coordinated to take into consideration the needs of free route operations in the airspace above.

Within FRA flight planning procedures are needed to be understandable and easy to use and also compatible with general procedures for the fixed ATS route network [4,5].The Initial Flight Plan Processing System of Eurocontrol (IFPS) performs routine flight plan processing in IFPS Zone (IFPZ) and checking in the context of variable lower levels of FRA in various parts of the European airspace [4]. Similarly, the IFPS performspermanent flight plans processing and checking for the crossing/violation of state boundaries and IFPZ boundaries by direct routes (DCT), whichfiled in appropriate flight plan fields.

The use of published in aeronautical publications FRA Horizontal entry points with associated FRA Horizontal exit points might be required in the most of cases to facilitate flight planning in FRA [5]. This is especially important in cases, where only limited combinations of entry/exit points are permitted within FRA.

Some DCTs might not be allowed for use by the airspace users due to different restrictions. Some of them might be connected with violation of horizontal and vertical DCTs restrictions and consequent plotting rules. The publication of such DCTrestrictions is ensured at the European network level, through the Route Availability 
Document (RAD) [4,6]. This approach ensuresconcordance of the airspace status within various FIRs (range of available FLs, prevention of penetration into uncontrolled airspace, availability period, etc.).

The current DCT limitations are applicable to administrative airspace boundary (FIR/ UIR), which does not always coincide with the operational airspace boundaries. The possibility of DCT flight planning across two or more FIR/ UIR boundaries is implemented in cross border FRA areas (for example, FRA Kyiv and FRA Dnipro were conjoined in cross-border FRA KIDRO [7]). This will require IFPS to compute and communicate to all ACCs entry/exit positions for their area of responsibility.

If the DCT limits are different in the airspace below the FRA, the IFPS calculation could raise errors for traffic flying in both airspaces. This is the case for the traffic climbing/descending between the FRA and the fixed ATS route network.

The IFPS restrictions in horizontal plane are connected with difference between IFPZ boundaries and state boundary of Ukraine. The vertical plane restrictions are connected with position of entry/exit FRA for departing/arriving aircraft.

The FRAU project,that is currently under implementation in Ukrainian airspace, takes into consideration restrictions and limitations of IFPS regarding restrictions in a horizontal and vertical plane. But calculation of these IFPS requirements are performed manually and consume a lot of time and human resources before every next step of FRAU implementation.

Theoretical solution of these issues and further creation of applied software tools will enable more efficient use of free route airspace, save time/resources of operational staff and make possible automated procedures for the routine technologic processes.

\section{Analysis of research and publications}

The documentation and publications regarding direct routes operations in FRA are mostly contained in ICAO documents and EUROCONTROL regulations [1,2,4-6], many of which are implemented in Ukraine on national level (FRAU Project) [7,8].
The crucial information about flight planning procedures within FRA, theconceptualFRAprinciples, the common flight planning limitations and rules, plans regarding the European Route Network Improvements, specific questions of FRA implementation and appropriate templates for airspace users are provided in $[1,4]$.

Somespecific questions of FRA operation, different limitations and restrictions, including the Route Availability Document (RAD) are available in [9]. The RAD is common reference document containing the policies, procedures and description for route and traffic orientation. It also includes route network and free route airspace utilisation rules and availability.

The description of DCT application and appropriate regulations in FRAare contained in Free Route Airspace Ukraine (FRAU) Operational Concept (Step 1, Scenario 1b) [8] and FRA UKRAINE Airspace Design - Working Plan [7].

The detailed explanation ofall aspects of DCT application and appropriate limitations are provided in Aeronautical Information Publication (AIP Ukraine) [10], which periodically updates (every AIRAC) and available for all domestic and foreign airspace users (in paper form and via Internet).

Complex processes of step-by-step integration of national Free Route Airspace areas into greater regional Free Route Airspace areas, principles of gradual improvement of air traffic flow and capacity management on tactical level and optimisation of European fixed air traffic services route network were analysed in $[11,12]$.

3. General description of algorithms of acceptability assignment for direct routes in Free Route Airspace of Ukraine

Use ofthe RAD Appendix 4 functionality makes possible to describe any FRA area enrouteDCT flight plan filing limitation in full compliance with provisions of ICAO Doc 4444 (PANS-ATM) [9].

Therestriction structure flexiblyallows any desired limitation of DCT horizontal and vertical limits inside FRA area. 
Y. Chynchenko, V. Kharchenko. Integrated Algorithm for Compiling and Assessment of Direct Routes Restrictions in Free Route Airspace of Ukraine

The short description of flight procedures regarding DCT and appropriate restrictions are published in AIP Ukraine [10]:

1. Within individual FRA areas, AOs may plan user-preferred trajectories by means of DCT between FRA Significant Points or via the existing ATS Route Network or a combination of both.

2. Within individual FRA areas there are no limitations for the maximum DCT distance and number of FRA Significant Points inserted in the FPL.

3. Planning DCT segments closer than $5 \mathrm{NM}$ to FRA border is not allowed except those, published in RAD.

4. Cross-border DCTs between FRAU and neighbouring FIR/UIR outside ofFRA Horizontal Entry/Exit Points are not allowed.

Therefore, no FPLs shall be filed via the Ukrainian airspace, deviating from the State restrictions defined in the RAD.Moreover, flights containing some horizontal and vertical issues are not allowed to enter FRAU and European FRA areas accordingly.

At the moment, in Ukraine exists some inconsistency and inaccuracy in a process of creation of DCT restrictions:

- NM system checks the proximity of DCTs to the AUAFRA border notmore than $\pm 0,5 \mathrm{~nm}$ width, but in Ukraine is established standard of $5 \mathrm{~nm}$ (due to RNAV5 routes width in upper airspace).

As a result, there is an urgent need of additional check for $5 \mathrm{~nm}$ offset, which is performed manually by engineering staff;

- difference of contours between State border of Ukraine and IFPZ border (State border more precise and detailed) - NM system checks DCTs on basis of IFPZ border, but correctcheck should be based on contours of State border of Ukraine (to prevent its violation).

In order to solvethese problems and automate appropriate calculations of main processes, we propose principles of acceptability assignmentfor algorithms to more correctly generate DCT restrictions (for insertion in RAD and further IFPS use) for such specific issues, as follows:

1. In a horizontal plane:

- issue with checking the proximity of DCTs close to the ATC Unit Airspace(AUA)FRA area border;

- issue with FRA area border "clipping".

2. In a vertical plane:

- issue with transition "laterally" via FRA (I) point;

- issue with transition "vertically" below FRA significant point.

4. The algorithm of correct generation of DCT restrictions for the selected issues in a horizontal plane

4.1. The issue with checking the proximity of DCTs close to the AUAFRA area border

The NM system is not checking the proximity of DCTs close to the AUAFRA area border more than $\pm 0.5 \mathrm{~nm}$ on both sides of the relevant AUA border(Fig. 1).

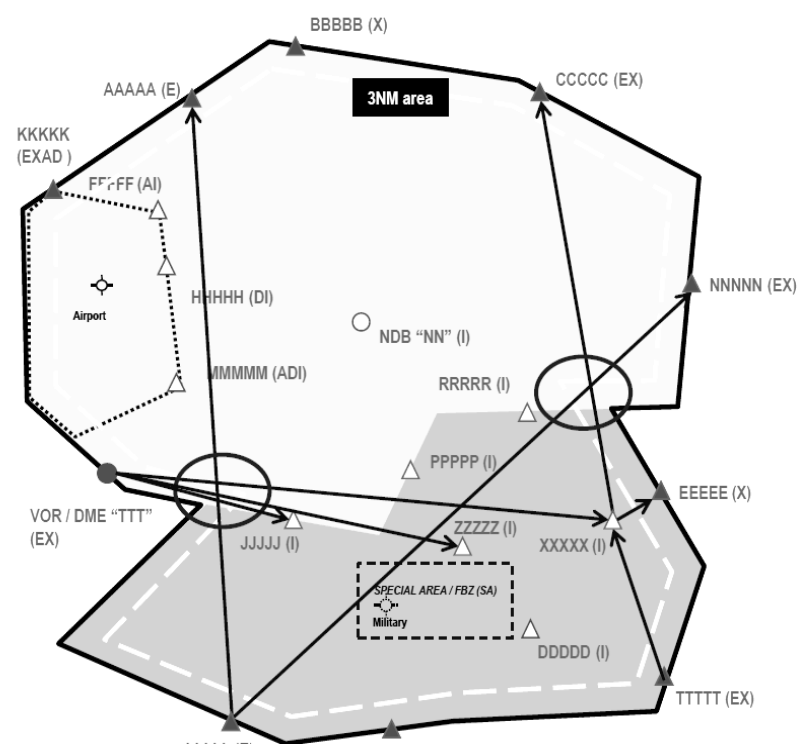

Fig. 1. Example of AUA FRA area border proximity violation

States/ANSPs may define restrictions valid for significant points in order to forbid all possible FRA DCTs in closeproximity to FRA area border.The example below shows the expression of unacceptable FRA DCTs:

No flights allowedbetween TTT and JJJJJ / ZZZZZ on any DCT combination.

The algorithm to more correctly generate DCT restrictions for the issue with checking the proximity of DCTs close to the ATC Unit Airspace (AUA)FRA area border, as follows (Fig. 2): 
Significant Points in adjacent FRA Area

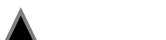

Adjacent FRA Area

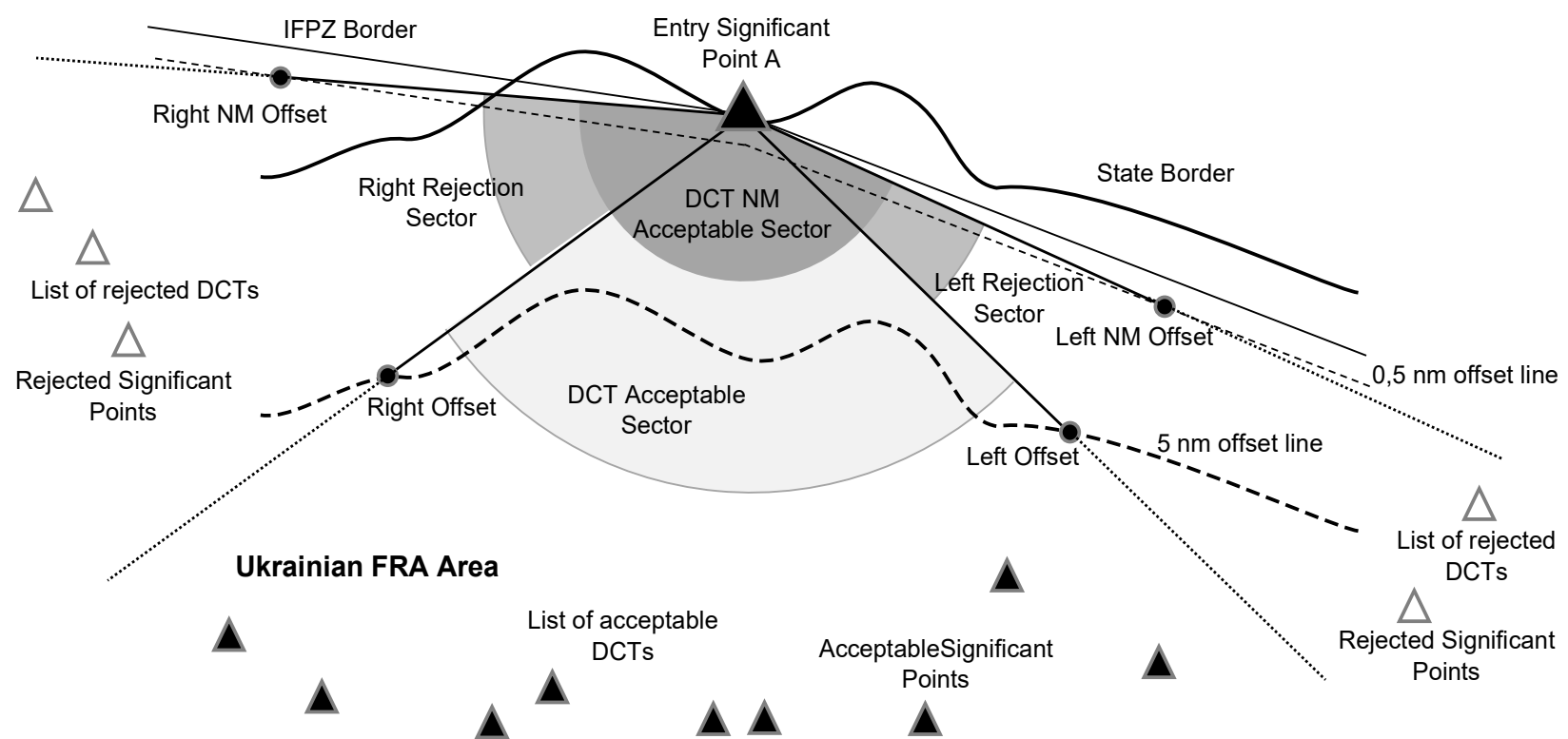

Fig. 2. The description of the Algorithm to more correctly generate DCT restrictions

1. Set the $0,5 \mathrm{~nm}$ offset line along the IFPZ border along the Ukrainian airspace.

2. Draw 2 directs linesof $15 \mathrm{~nm}$ length (NM system tolerance) from the Entry Significant Point A to reference points on the $0,5 \mathrm{~nm}$ offset line (to the left and to the right directions) - the Left NM Offset and the Right NM Offset.

3. Segregate sector of airspace between the Left NM Offset and the Right NM Offset (the DCT NM Acceptable Sector) and from the set of all significant points $\left(M_{P T}^{A L L}\right)$, choose set of those Exit significant points $\left(M_{P T}^{N M}\right)$, which are located inside the DCT NM Acceptable Sector $\left(\alpha\left(P T_{A C}^{N M}\right)\right.$ and add them to the List of NM acceptable DCTs $\left(D_{D C T}^{N M}\right)$ for the Entry Significant Point A.

4. Set $5 \mathrm{~nm}$ offset line along the State border of Ukraine.

5. Draw 2 directs linesof $15 \mathrm{~nm}$ length(NM system tolerance) from the Entry Significant Point A to points on the $5 \mathrm{~nm}$ offset line (to the left and to the right directions) - the Left Offset and the Right Offset.

6. Segregate sector of airspace between the Left Offset and the Right Offset (the DCT Acceptable Sector) and from the set of all significant points $\left(M_{P T}^{A L L}\right)$, choose set of those Exit significant points ( ), which are located inside the DCT Acceptable Sector $\left(M_{P T}^{A C}\right)$ and add them to the List of acceptable DCTs $\left(D_{D C T}^{A C}\right)$ for the Entry Significant Point A:

$$
\begin{aligned}
& M_{P T}^{A C}=\left\{P T_{1}, \ldots, P T_{i}, \ldots, P T_{N}\right\}, \\
& P T_{i} \in M_{P T}^{A L L} \mid \alpha\left(P T_{A}\right)
\end{aligned}
$$

7. Segregate 2 sectors of airspace between the Left Offset and the Left NM Offset (the Left Rejection Sector) and between the Right Offset and the Right NM Offset (the Right Rejection Sector) and from the set of all significant points $\left(M_{P T}^{A L L}\right)$, choose set of those Exit significant points $\left(M_{P T_{L T}}^{R J}\right.$ and $\left.\alpha\left(P T_{R}^{L T}\right)\right)$, which are located inside the Left Rejection Sector $\left(\alpha\left(P T_{R}^{R T}\right)\right)$ and the Right Rejection Sector $\left(D_{D C T_{L T}}^{R J}\right)$ and add them to the Lists of rejected DCTs $\left(D_{D C T_{L T}}^{R J}\right.$ and $D_{D C T_{R T}}^{R J}$ ) for the Entry Significant Point A(these DCTs were approved by NM system, but do not meet national requirements of Ukraine):

$$
\begin{aligned}
& M_{P T_{L T}}^{R J}=\left\{P T_{1}, \ldots, P T_{i}, \ldots, P T_{N}\right\}, \\
& P T_{i} \in M_{P T}^{A L L} \mid \alpha\left(P T_{R}^{L T}\right) \\
& M_{P T_{R T}}^{R J}=\left\{P T_{1}, \ldots, P T_{i}, \ldots, P T_{N}\right\},
\end{aligned}
$$


Y. Chynchenko, V. Kharchenko. Integrated Algorithm for Compiling and Assessment of Direct Routes Restrictions in Free Route Airspace of Ukraine

$$
P T_{i} \in M_{P T}^{A L L} \mid \alpha\left(P T_{R}^{R T}\right)
$$

8. Repeat items 1-7 for every Entry Significant Point in Ukrainian airspace.

As a result of this algorithm, for every Entry Significant point in Ukrainian airspace will be composedthe List of acceptable DCTs (in concordance with national regulations) ( $D_{D C T}^{A C}$ ) and the Lists of rejected DCTs $\left(D_{D C T_{L T}}^{R J}\right.$ and $\left.D_{D(T \mathrm{D} \tau}^{R J}\right)$ :

$M_{P T}^{N M}=M_{P T}^{A C} \cup M_{P T_{L T}}^{R J} \cup M_{P T_{R T}}^{R J}$

$M_{P T}^{A C} \in M_{P T}^{N M} \Leftrightarrow\left\{P T_{N} \mid\left(P T_{N} \in M_{P T}^{N M}\right) \wedge\left(P T_{N} \in M_{P T}^{A C}\right), M_{P T}^{A C} \neq M_{P T}^{N M}\right\}$ $D_{D C T}^{N M}=D_{D C T}^{A C} \cup D_{D C T_{L T}}^{R J} \cup D_{D C T_{R T}}^{R J}$

$D_{D C T}^{A C} \in D_{D C T}^{N M} \Leftrightarrow\left\{P T_{N} \mid\left(P T_{N} \in D_{D C T}^{N M}\right) \wedge\left(P T_{N} \in D_{D C T}^{A C}\right), D_{D C T}^{A C} \neq D_{D C T}^{N M}\right\}$

\subsection{The issue with FRA area border "clipping"}

The term "clipping" is used in the case when any planned DCT intends to exit and then re-enters the relevant FRA area.The example is presented below (Fig.3).

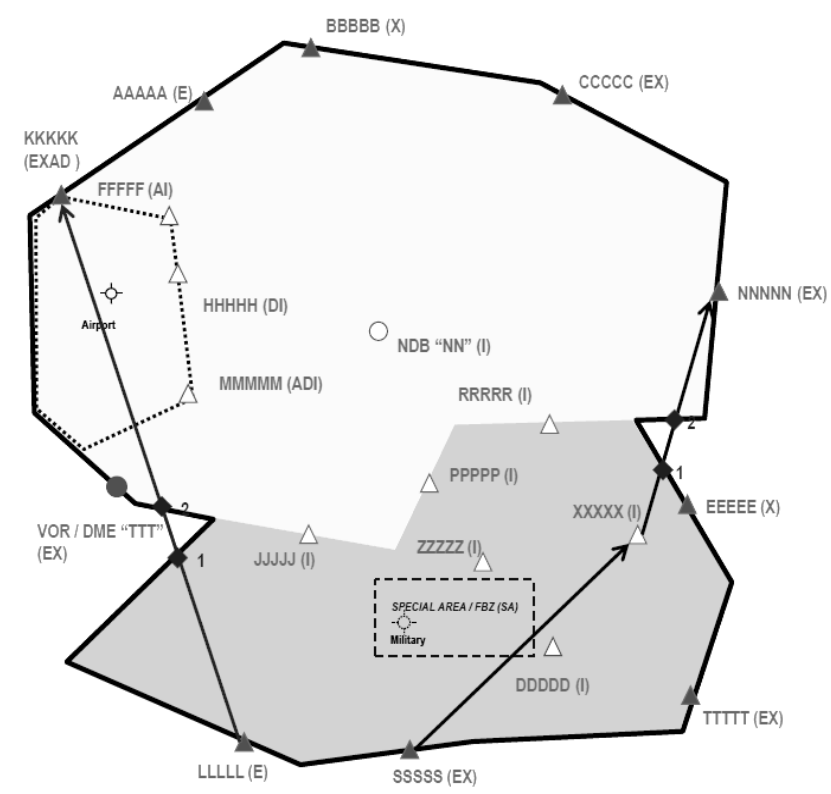

Fig. 3. Example of FRA (AUA) border "clipping" rejection

The relevant cross-border and en-route FRA DCT restrictions defining the FRAEntry / Exit points (how to penetrate and leave the FRA area laterally) as well as theconditions to cross the FRA area prevent such a DCT to be filed. The relevant DCTis unavailable as the flight attempts to cross the FRA area (AUA) border via nondefinedFRA significant point.
The algorithm to more correctly generate DCT restrictions for the issue with FRA area border "clipping", as follows:

1. Perform all items of the Algorithm to more correctly generate DCT restrictions for the issue with checking the proximity of DCTs close to the ATC Unit Airspace (AUA)FRA area border (See paragraph 4.1).

2. If exist the $5 \mathrm{~nm}$ offset line inside the DCT Acceptable Sector, then draw direct line from the Entry Significant Point A to maximum reference point inside the DCT Acceptable Sector - the Revised Left/Right Offset.

3. Segregate sector of airspace between the Revised Left/Right Offset and the Left/Right Offset - the Revised DCT Acceptable Sector.

4. Select all Exit significant points, which are located inside the Revised DCT Acceptable Sector and add them to the Revised List of acceptable DCTs for the Entry Significant Point A.

5. If exist $15 \mathrm{~nm}$ beyond Ukrainian airspace ("clipping area"), then draw direct line from the Entry Significant Point A along the exactly 15 $\mathrm{nm}$ clipping area - the Revised Left/Right NM Offset.

6. Segregate sector of airspace between the Revised Left/Right NM Offset and the Revised Left/Right Offset - the Revised Right/Left Rejection Sector.

7. Select all Exit significant points, which are located inside the Revised Right/Left Rejection Sector and add them to the Revised List of rejected DCTs for the Entry Significant Point A. The Revised List of acceptable DCTs and the Revised list of rejected DCTs should be included into the RAD Appendix 4 and used by the Eurocontrol NM systems for check of every flight plan and their final approval/rejection.

5. The algorithm of correct generation of DCT restrictions for the selected issues in a vertical plane

5.1. The issue with transition "laterally" via FRA (I) point

States/ANSPs might require transit not via a defined/allowed FRAsignificant point but referenced to it (before or after) in order to allow a smooth flightprofile. 
The relevant cross-border FRA DCT restriction can allow such "lateral"transition. It forbids cross-border operations between airspace with ATS routenetwork and FRA area and vice-versa except via explicitly defined for that purposeFRA significant points (I). The example is presented below (Fig.4).

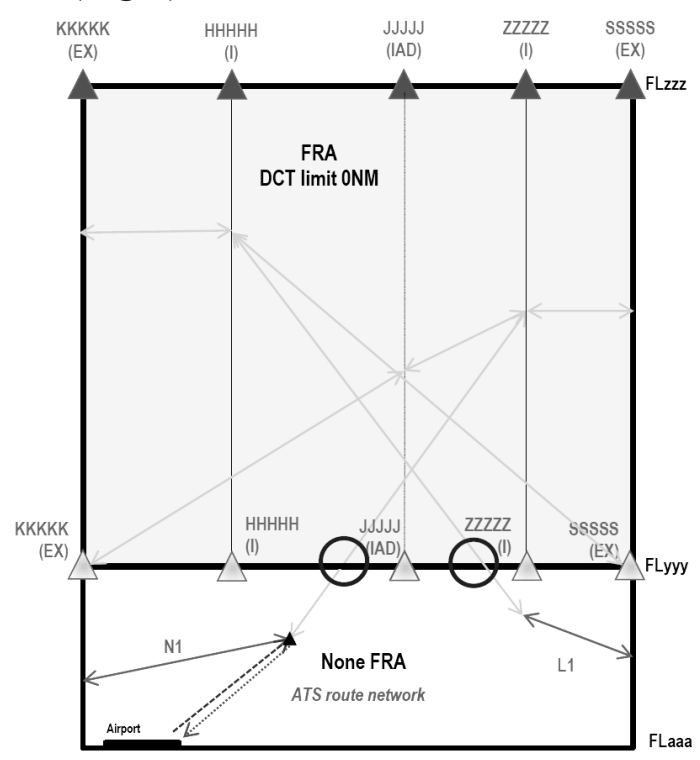

Fig. 4. Example of FRA (AUA) border "clipping" rejection

The algorithm to more correctly generate DCT restrictions for the issue with transition "laterally" via FRA (I) point, as follows:

1. If descending aircraft leaves FRA not in prescribed intermediate point, then calculate the actual trajectory and profile of descending aircraft.

2. Check possible intersections of trajectory and profile of descending aircraft with restricted area in airspace under the FRA area.

3. If intersection exists, then check status of restricted area.

4. If restricted area has activated status, then perform immediate ATC coordination to prevent penetration of descending aircraft into activated restricted airspace.

5. Repeat items 1-5 for every descending aircraft, that leaves FRA not in prescribed intermediate point.

5.2. The issue with transition "vertically" below FRA significant point

States/ANSPs might require transit below the lower vertical limit of adefined/allowed FRA significant point in order to allow a smooth flight profile. Therelevant cross-border FRA DCT restriction can allow such "vertical" transition by artificially expanding the lower vertical limit of all required FRA Intermediatepoints (I).

The cross-border operations between airspace with ATS route networkand FRA area and viceversa are allowed when the trajectory upper limit is abovethe FRA (I) "expanded lower" limit(Fig.5).

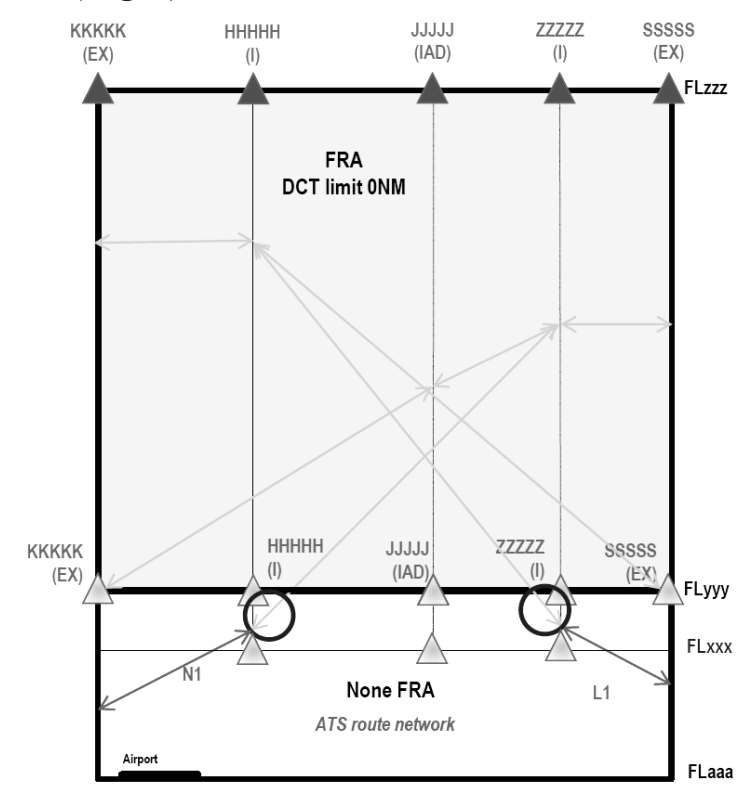

Fig. 5. Example of FRA / non-FRA transition "below" defined FRA points

The algorithm to more correctly generate DCT restrictions for the issue with transition "vertically" below FRA significant point is similar to one, which is provided in paragraph 5.1 .

6 . The principles of creation of applied software for automatic processing of direct routes at flight planning phase

The DCT restrictions acceptability assignment tool (DCT RAAT) is a stand-alone desktop application, currently under construction, expected to be used by the Air Navigation Service Provider (UkSATSe) strategic traffic flow organization, scenario preparation for fasttime simulations and ad-hoc studies at the local level. The proposed list of main four tasks for DCT RAAT includes:

- check and validation of generated DCT restrictions for the issue with checking the 
Y. Chynchenko, V. Kharchenko. Integrated Algorithm for Compiling and Assessment of Direct Routes Restrictions in Free Route Airspace of Ukraine

proximity of DCTs close to the ATC Unit Airspace (AUA) FRA area border;

- check and validation of generatedDCT restrictions for the issue with FRA area border "clipping";

- check and validation of generatedDCT restrictions for the issue with transition "laterally" via FRA (I) point;

- check and validation of generatedDCT restrictions for the issue with transition "vertically" below FRA significant point.

The DCT RAAT includes databases with static information about Ukrainian airspace and State boundary and IFPZ boundary. Dynamic data with examples of traffic (to check real DCT restrictions) is also desirable.

The DCT RAAT creates final report containing list of DCT restrictions (based on above mentioned list of tasks) for further forwarding to RAD and use in IFPS.

\section{Conclusions}

In this research wereconsideredICAO and Eurocontrol principles of DCT restrictions creation and their processing in Route Availability Document with further use in the Integrated Initial Flight Plan Processing System.

Specific inconsistency and inaccuracy in a process of creation of DCT restrictions in Ukraine wereanalysed for specific issues in horizontal and vertical plane. The principles of acceptability assignment for algorithms to more correctly generate DCT restrictions were proposed for such specific issues:

- issue with checking the proximity of DCTs close to the ATC Unit Airspace (AUA)FRA area border;

- issue with FRA area border "clipping".

- issue with transition "laterally" via FRA (I) point;

- issue with transition "vertically" below FRA significant point.

These algorithms might help more correctly generate DCT restrictions, resulting in more efficient use of free route airspace of Ukraine, saving time/resources of operational staff and possibility of automated procedures for the routine technology processes.
As a practical implementation of proposed algorithms, the stand-alone desktop applicationThe DCT restrictions acceptability assignment tool (DCT RAAT) was suggested, with functionality to automatically process algorithms and generate RAD-compatible reports (the tool is currentlyunder construction).

For correct operation of the DCT RAAT, the databases with static information about Ukrainian airspace, State boundary data array and IFPZ boundarydata array are required.

\section{References}

[1] European Route Network Improvement Plan. Part 1 - European Airspace Design Methodology - Guidelines. Eurocontrol, 2020. 276 p.

[2] European Route Network Improvement - Part 3. Airspace Management Handbook, Procedures for Airspace Management. Eurocontrol, 2019, $332 \mathrm{p}$.

[3] Safety assessment in air traffic management system regarding Free Route Airspace implementation.UkSATSE, 2014,103 p.

[4] NM Flight Planning Requirements Guidelines. - Brussels: EUROCONTROL, 2018, $195 \mathrm{p}$.

[5] Free Route Airspace Design Guidelines. Eurocontrol, 2019, 38 p.

[6] Free Route Airspace (FRA) Application in NMOC - Guidelines. Eurocontrol, 2017, 74 p.

[7] FRA UKRAINE (FRAU) Airspace Design, Working Plan. UkSATSE, 2018, 24 p.

[8] Free Route Airspace Ukraine (FRAU) Operational Concept, Step 1 - Scenario 1 b. UkSATSE, 2018, 29 p.

[9] European Route Network Improvement Plan (ERNIP) - Part 4: Route Availability Document User Manual. Eurocontrol, 2020, 36 p.

[10] Aeronautical Information Publication. UkSATSE, 2021.http://aisukraine.net/titul_ en.php.

[11] Chynchenko Yu.,Kharchenko V. (2021). The Free Route Airspace Ukraine implementation cornerstones. Proceedings of the National Aviation University,vol. 1, pp. 6-12.

[12] Kharchenko V., Chynchenko Yu. (2016). Models of qualitative estimation of air traffic flows and capacity in terminal control areas.Proceedings of the National Aviation University,vol. 4, pp. 7-13. 


\section{Ю.В. Чинченко ${ }^{1}$, В.П. Харченко ${ }^{2}$}

Інтегрований алгоритм побудови та оцінки обмежень для прямих маршрутів у повітряному просторі вільних маршрутів України

${ }^{2}$ Національний авіаційний університет, просп. Любомира Гузара, 1, Київ, 03058, Україна

E-mails: 'chynchenko@gmail.com, ${ }^{2 k h a r c h @ n a u . e d u . u a ~}$

У статті описані принципи прийнятності призначення для обмежень прямих маршрутів у повітряному просторі вільних маршрутів України для публікащії у Документі з доступності маршрутів та подальшого використання у Інтегрованій системі початкової обробки планів польотів Свроконтролю. Запропоновані алгоритми коректного створення обмежень для прямих маршрутів для визначених випадків у горизонтальній та вертикальній площині. У якості основного критерію з прийняття рішення для иих алгоритмів було обранонайкоротшу відстань до державного кордону (у горизонтальній площиині) та просторове положення (місцезнаходження) повітряного судна (у вертикальній площині).

Ключові слова: обмеження для прямих маршрутів, концепиія повітряного простору вільних марирутів, Документ з доступності маршрутів, організація потоків повітряного руху та пропускної здатності, Інтегрована система початкової обробки планів польотів, повітряний простір вільних мармрутів України.

\section{Ю.В. Чинченко ${ }^{1}$, В.П. Харченко}

\section{Структура и требования к универсальному учебному тренажеру для беспилотных авиационных} комплексов

12 Национальный авиационный университет, просп. Любомира Гузара, ${ }^{1}$, Киев, Украина

E-mails: ${ }^{1}$ chynchenko@gmail.com, ${ }^{2} \mathrm{kharch} @$ nau.edu.ua

В статье описаны принципь приемлемости назначения для ограничений прямых маршрутов в воздушном пространстве свободных маршрутов Украины для публикачии в Документе по доступности маршрутов и дальнейтего использования в Интегрированной системе первоначальной обработки планов полетов Евроконтроля. Предложены алгоритмы корректного создания ограничений для прямых маршрутов для определенных случаев в горизонтальной и вертикальной плоскости. В качестве основного критерия принятия решения для этих алгоритмов было избрано кратчайтее расстояние до государственной гранищы (в горизонтальной плоскости) и пространственное положение (местонахождение) воздушного судна (в вертикальной плоскости).

Ключевые слова: ограничения для прямых маршрутов, концепция воздушного пространства свободных маршрутов, Документ по доступности маршрутов, организаиия потоков воздушного движения и пропускной способности, Интегрированная система первоначальной обработки планов полетов, воздушное пространство свободных марирутов Украины.

\section{AUTHORS:}

Yuriy Chynchenko (1976). Candidate of Volodymyr Kharchenko(1943). Doctor of Engineering. Associate Professor.

Technical Sciences, Professor.

Doctoral candidacy, National Aviation University, National Aviation University, Kyiv, Ukraine.

Kyiv, Ukraine.

Education: The State Flight Academy of Ukraine, Kirovograd, Ukraine (1998).

Researcharea: freerouteairspaceimplementation, air traffic flow and capacity management, safety of flights.

Publications: 143. Education: National Aviation University. Research area: management of complex sociotechnical systems, air navigation systems and automatic decision-making systems aimed at avoidance conflict situations, space information technology design, air navigation services in Ukraine provided by CNS/ATM systems. Publications: 541. 